ISSN 0103-5150

Fisioter. Mov., Curitiba, v. 28, n. 1, p. 141-148, Jan./Mar. 2015

Licenciado sob uma Licença Creative Commons

DOI: http://dx.doi.org.10.1590/0103-5150.028.001.A014

(c) (i)

\title{
Assessment of the perception of aerobatic pilots regarding flight activity
}

\author{
Avaliação da percepção de pilotos de acrobacias \\ sobre sua atividade de voo
}

\author{
Suraya Gomes Novais Shimano ${ }^{[a]}$, Isabel Aparecida Porcatti de Walsh ${ }^{[a]}$, \\ Marisa de Cássia Registro Fonseca ${ }^{[b] *}$ \\ [a] Universidade Federal do Triângulo Mineiro (UFTM), Instituto de Ciências da Saúde, Departamento de Fisioterapia \\ Aplicada, Uberaba, MG, Brazil \\ [b] Universidade de São Paulo (USP), Faculdade de Medicina de Ribeirão Preto, Ribeirão Preto, SP, Brazil
}

\begin{abstract}
Introduction: In order for an ergonomic assessment to be comprehensive, it must include the workers' perception in the process of identifying and eliminating risks, aimed at improving their health, and living and working conditions. Objective: To assess the perception of pilots from the Brazilian Air Demonstration Squadron (EDA) regarding their own work. Materials and methods: This was a qualitative cross-sectional study of descriptive nature. A semi-structured interview was conducted with all EDA pilots, whose answers were recorded and later transcribed and categorized according to the method of content analysis proposed by Bardin. Results: Mean age was $34 \pm 4$ years and mean time at EDA, $24 \pm 21$ months. Response categorization demonstrated that heat was the most commonly cited external factor, followed by Gz force. Regarding physical overload, the most common complaint regarded the upper right limb during flight. Considering physical overload during flight, rotating the control stick laterally was the most commonly mentioned
\end{abstract}

\footnotetext{
* SGNS: PhD, e-mail: surayagnovais@gmail.com IAPW: PhD, e-mail: andewalsh@terra.com.br MCRF: PhD, e-mail: marisa@fmrp.usp.br
} 
maneuver. Communication among group members during work (both administrative and in flight) was perceived by most as open and direct. Conclusion: The pilots' perception allowed a broad assessment of their working conditions, which can help direct specific future assessments (i.e. biomechanical) and interventions that can ensure health gains and maintenance for this population. The current study provided great insight into the working conditions of Brazilian Air Force demonstration pilots, leading to the possibility of providing them with better health care.

Keywords: Occupational health. Human engineering. Military personnel.

\section{Resumo}

Introdução: Uma análise ergonômica completa deve envolver os trabalhadores nos processos de identificação e eliminação dos riscos para o alcance de melhorias em suas condições de saúde, vida e trabalho. Objetivo: Avaliar a percepção de pilotos do Esquadrão de Demonstração Aérea (EDA) sobre seu trabalho. Materiais $\boldsymbol{e}$ métodos: Estudo qualitativo, transversal e de caráter descritivo. Foi aplicada uma entrevista semiestruturada para todos os pilotos do EDA, com gravação e posterior transcrição das respostas, que foram categorizadas segundo o método proposto por Bardin. Resultados: A idade média foi de $34 \pm 4$ anos e o tempo no EDA, 24 \pm 21 meses. A categorização das respostas demonstrou que o calor foi o fator externo mais citado como fonte de desconforto, seguido da força Gz. Quanto à sobrecarga física, a maior frequência de queixas foi no membro superior direito e durante o voo. 0 movimento relatado como o que mais sobrecarregava o corpo durante o voo foi o giro lateral do manche. A comunicação entre os membros do grupo durante o trabalho (tanto administrativo quanto em voo) foi percebida pela maioria como sendo aberta e direta. Conclusão: A percepção dos pilotos permitiu uma visão ampla de suas condições de trabalho, direcionando as avaliações específicas futuras (entre elas, a biomecânica) e as intervenções que assegurem o ganho e a manutenção da saúde deles. Este estudo abre caminho para um maior conhecimento e uma consequente assistência mais adequada dos militares da Força Aérea Brasileira.

Palavras-chave: Saúde do trabalhador. Ergonomia. Militares.

\section{Introduction}

The impact of work on people's health has been investigated by several different professionals (1-4) and includes the repercussions of work-related factors on health and sense of well-being (5). Workers should be effectively involved in the process of identifying and eliminating such risks (6) as the consequences of work inadequacies are felt directly on their bodies (7).

In this sense, human engineering promotes a holistic and person-centered approach towards designing work systems that take into account physical, cognitive, social, organizational and environmental aspects (8-10). Thus, in this model, qualitative assessments are just as important as quantitative ones (11). Qualitative research makes use of instruments such as questionnaires, interviews and scales, among others (8). Semistructured interviews follow a script that makes it easier to obtain responses (12) from participants and allows for the identification of population groups and job tasks that are subject to risks (13). The use of the semi-structured interview in human engineering is based on the assumption that workers are capable of defining sensations associated with overload, as well as potential injury situations at work (14).

In the specific case of the Air Demonstration Squadron (EDA) of the Brazilian Air Force (FAB), popularly known as the Esquadrilha da Fumaça (Smoke Squadron, in English), pilots spend a great portion of their total work time in flight, as there is a high frequency of aerobatic presentations and that involve long trips to their destinations. Thus, assessing the perception of pilots can help understand the true conditions experienced by these workers during flight.

The EDA is composed of 13 pilots with a secondary education level obtained at the Air Force Academy (AFA). They possess at least 1,500 hours 
of flight practice and work with T27-Tucano aircrafts. Individual protection gear consists of flame-resistant coveralls, boots, masks and gloves, which altogether weigh over $5 \mathrm{~kg}$. Pilots are practically immobilized by both chest and crotch belts so that they remain fastened to the seat during inverted flights.

The selection process for demonstration pilots takes into account anthropometric criteria (15), flight history, and professional and personal profiles, all in accordance with the position assumedduring aerobatic maneuvers. The demands are intense, for in addition to being responsible for complex flight activities, these pilots must also complete AFA administrative tasks.

Many hours of training are required for aerobatic maneuvers to be performed with precision. They are complex and require that pilots be not only highly specialized, but also possess great cognitive and physiological adaptation capabilities.

Excessive amounts of maneuvers lead to great physical overload due to g-forcepresent during curves and which increase with the aircraft's speed. Therefore, although such strains can lead to increased muscle strength and performance (16), pilots can also present pain symptoms, vision changes, cardiac arrhythmias, compressed vertebrae and even unconsciousness, which can lead to fatal accidents (17).

Therefore, it is essential to conduct an ergonomic analysis of EDA pilots' in-flight working conditions that values their body self-perception during flight and work routine, thus integrating the views of the ergonomist and flight workers. Such an integration deepens the understanding of the pilots' daily work routine, including aspects such as coworker interaction, rules, obligations, work schedule and each pilot's point of view regarding the group and the work they carry out for the AFA and society.

This broadened perspective of demonstration pilots' working conditions will allow to identify work hazards and direct interventions towards controlling and eliminating them, ensuring the maintenance of these workers' health.

The objective of this study was to assess body selfperception of EDA pilots during and after flight, taking into consideration the following factors: Conditions inside the cockpit, discomfort or pain experienced during or after flight, movement of greatest overload during maneuvers, work place communication and interpersonal relationships among coworkers.

\section{Materials and methods}

This was a qualitative, cross-sectional and descriptive study. It was approved by the research ethics committee of the Hospital das Clínicas, Ribeirão Preto School of Medicine, University of São Paulo, in June 2006, no. 7674/2006.

In addition to physical aspects, social and organizational factors were also taken into consideration in order to provide a broader view of the pilots' work routine, considering workers within a biopsychosocial context $(18,11)$.

To avoid the reductionism that results from only using numerical data for ergonomic analysis, we adopted a qualitative approach (content analysis) to study the pilots' relationships, perceptions and opinions (12).

All 13 EDA pilots participated in the study, duly informed of and in agreement with the justification, objectives and procedures to be conducted.The interviews were carried out individually in the AFA's aeromedical room, as it was a calm and quiet location. All interviews were recorded on a Sony ${ }^{\mathrm{TM}}-\mathrm{MP} 3$ player, exported to Windows Media Player ${ }^{\mathrm{TM}}$-software, and then transcribed in their entirety for subsequent analysis.

First, data regarding the pilots' individual characteristics were gathered and then they answered open-ended questions aimed at recording the pilots' perceptions. The questions were as follows:

- How do you perceive your body during flight?

- Regarding your general comfort during flight, how would you describe the cockpit conditions?

- Do you feel any discomfort or pain during or after flight? Tell me about it.

- In your opinion, what movement most overloads your body when performing maneuvers?

- How would you describe the communication among coworkers?

- What is the interpersonal relationship among pilots like? Tell me about it.

Before the study began, the interview script was pretested in order to establish the consistency of responses and to analyze if the questions were suited to the objectives of the study. The questions were well understood by participants and therefore none was altered. 
Content analysis was initiated immediately after the interviews so that the discourse could be more accurately categorized, as the intonation and expressions associated with the discourse would be easier to recall. The analysis was conducted according to the technique proposed by Bardin (19), which consists of pre-analysis, analytical description and inferential interpretation.

Interview answers were categorized first by differentiating among recording units and then by regrouping them. The results were later processed according to frequency of emergence of such units in order to better direct the interpretations.

\section{Results}

All 13 pilots were male, mean age of $34 \pm 4$ years, mean flight hours of 3,655 $\pm 1,120$ and mean time at EDA of $24 \pm 21$ months.

Regarding body perception during flight, we were able to identify different opinions that led to the construction of three categories: "External Factors," Physical Overload," and "Training," as presented in Table 1.

The movement that most caused overload during flight was rotating the control stick laterally, which was mentioned with the highest frequency, followed by others of less relevance. This particular movement was often referenced to by contrasting initial training with current activities (when pilots were admitted to the EDA and underwent several training sessions versus now, when they are better adapted to the movement). These responses were thus categorized according to these two flight periods, as illustrated in Table 2.

Communication among group members fell into one of two categories: "Type of communication" and "Moment of communication".

Considering type of communication, seven pilots characterized it as open and direct. All pilots made mention to communication as related to flight. On-ground communication was strictly flight-associated, both at briefing (when the group goes over the demonstration procedure in detail) and debriefing meetings (post-flight observations and comments on the mistakes and strong points of the presentation).

\section{Discussion}

The pilots presented a history of 3,665 $\pm 1,120$ hours of flight, which is a testament to the EDA's preference for more experienced pilots. Although the pilots in our study were all male, the AFA already admits female cadets. However, the number of women who become official aviators is still small. The mean age of the pilots, $34 \pm 4$ years, shows that the EDA selects relatively young pilots to compose the squadron.

Table 1 - Pilots' body self-perception in aircraft during flight

\begin{tabular}{lll}
\hline Categories & Recording units & Frequency of recording units \\
\hline & $\begin{array}{l}\text { Being bothered by environmental } \\
\text { conditions (wind, turbulence, heat) } \\
\text { Feeling discomfort when aircraft changes } \\
\text { position (nose tilted downwards or fast } \\
\text { curves - Gz force) } \\
\text { Feeling uncomfortable wearing PPEs } \\
\text { (belts, helmets, masks, hearing protection } \\
\text { plugs) } \\
\text { Feeling uncomfortable in seat }\end{array}$ & 8 \\
& Upper right limb & 11 \\
\hline Physical overload & Lower limbs \\
Spinal cord & 10 \\
\hline Training & Lack of physical adaptation associated & 7 \\
\hline with excessive training & 5 \\
\hline
\end{tabular}


Table 2 - Pilots' perception on which movement most overloads body during flight

\begin{tabular}{llc}
\hline Categories & Recording units & Frequency of recording units \\
\hline Initial training & Rotating control stick laterally & 7 \\
\hline \multirow{2}{*}{ Current activities } & Rotating control stick laterally & 8 \\
& Pulling control stick back & 2 \\
\hline
\end{tabular}

Mean time at the EDA of $24 \pm 21$ months presented variations. For example, the commander had been there for six years, having been offered the position after four years as a pilot. It is important to highlight that these pilots are granted professional stability, which minimizes the stress associated to possible job loss.

Due to the lack of studies on this theme among air force personnel, discussing the data produced by our content analysis based on theoretical frameworks was an inevitable challenge.

By relating the pilots' personal characteristics and their accounts, we were able to infer some probable causes for the symptoms presented. For example, some pilots who mentioned lower back pain had worked as helicopter pilots, which has been shown to overload the lower back with vibration (20).

The results of content analysis regarding the pilots' perception of their own body when in the aircraft are presented in Table 1. Heat was the most mentioned external factor, due to the lack of solar protection of the transparent cockpit roof and the suit worn. During a post-flight observation, the aircraft's external thermometer recorded $38^{\circ} \mathrm{C}$. However, according to these pilots' accounts, the thermometer had already registered temperatures higher than $50^{\circ} \mathrm{C}$, depending on the location of the demonstration. This demonstrates the intensity of thermal stress to which they are submitted.

According to Temporal (17), excessive sweating causes loss of electrolytes, which unless quickly replenished, can cause tachycardia, hypotension and decreased peripheral circulation. Heat exposure can alter cognitive function, reaction time, physical strength and resistance, and increase mean error.

Thermal stress was measured by Jain, Chawla and Tyagi (21), who found that the aircraft's air conditioning system was not sufficient to prevent heating during flight.
To avoid such discomfort, flight practice always takes place at late afternoon. During long trips, pilots cover the inner part of the cockpit with a metallic reflective material that provides solar protection. Despite the simplicity of such measures, the pilots consider them to be greatly significant to their routine.

Few pilots mentioned factors such as noise and turbulence. The use of hearing protection plugs and the fact that they have adapted to flight conditions reduce their perception of these forms of stress, even though noise levels over $63 \mathrm{~dB}$ (a level lower than that of the T27 TUCANO turbines) impairs communication and can lead to significant hearing loss (22).

Most pilots related their perception of discomfort with respect to the aircraft's position to g-force. This finding corroborates that of Rickards and Newman (23), who found that $98 \%$ of pilots report visual and cognitive disturbances and abnormal sensation in limbs during flight.

Unfortunately, these pilots do not have anti-gravity suits. One solution for avoiding greater problems is to strengthen abdominal and neck muscles to increase their resistance to g-force.

Perception regarding personal protection equipment (PPE) was related to discomfort due to weight (helmet), hindered movement (belts) and increased heat sensation (coveralls and mask). Seatbelts are very tight, especially the crotch belt, to avoid body dislocation in seat during inverted flights. This causes discomfort and injuries (confirmed by the bruises on recently-admitted pilots). Such discomfort tends to be noticed more during long trips than during presentations. In the latter, pilots are more concerned with the maneuvers than with their own bodies.

The results regarding seat-related discomfort are justified, as the seats were manufactured in England and were therefore anthropometrically inadequate for Brazilian pilots. These dimensions were compared to those presented by Goossens, Snijders and Fransen 
(24), in accordance with Aerospace Standard 290B (AS 290B) seat regulations. Only distance from floor was found to be in compliance with the norm. All other measurements, such as seat depth and backrestheight and width were not within standardized norms. The upholstery in the present study was also considered inadequate, as was the case in another study (25) that evaluated Australian Air Force pilots and found that seat cushions were not changed frequently enough, causing extreme discomfort.

The results of content analysis regarding physical overload found a high frequency of complaints related to the upper right limb, which moves the control stick. Discomfort is a consequence of the strain of sudden movements (rotating the stick quickly to begin a maneuver) and the overload imposed by $+G$ force, which increases the weight of the limb and, consequently, muscle overload (26).

Some pilots also noticed changes in their lower limbs due to pedal activation and changing the direction of the aircraft's nose (left and right).

Complaints regarding the spinal cord corroborated the results of Silva (27), who assessed 446 FAB aviators and found that $41.3 \%$ of aviators in general and $34.6 \%$ of fighter pilots reported back pain. Of these, $7.2 \%$ had taken leaves of absence due to disability.

With regard to types of training, eight pilots reported feeling differences between initial training and current work activities. This perception is related to the fact that on admittance to the EDA, pilots are not adapted to this kind of physical overload and need time to adjust to such physiological changes (22).

Regardless of what point the pilots were in their training, rotating the control stick laterally was the perceived movement of greatest overload with most mentions, as illustrated in Table 2. On admittance to the EDA, pilots must carry out three 50-minute flights dedicated exclusively to spin training with three-minute intervals between each flight. Beginning pilots dedicate an average of 70 hours to such training. After this initial period, muscles begin to adapt due to the specificity principle, leading to increased strength in the muscles activated during flight (28). Furthermore, flights become less frequent, which also leads to a reduction in pain symptoms.

According to the pilots, there is a compensatory button that relieves the force exerted on the control stick. However, beginning pilots do not use it because their attention is primarily focused on a great quantity of operational information. Therefore, their priority is not directed towards relieving the exertion of physical force. Thus, those who have the least training and performance apply greater force in movements and are submitted to intense training periods with no time for muscle recovery, ideal conditions for developing workrelated musculoskeletal disorders (WMSDs) (29).

On the topic of interpersonal communication, seven pilots defined it as open and direct, probably due to the fact that the group requires a very harmonious coexistence, as they must develop mutual trust, especially during flights. Five pilots touched on the topic of hierarchy, due to the military context. The difference between this squadron and the others is the high degree of freedom of dialogue, as pilots must always support one another, be it during flight or on ground. This openness facilitates understanding among group members and dilutes any communication problems.

Interestingly, all pilots associated communication exclusively with flight situations when asked about the moment of communication. Apparently, this was due to the fact that although they work in the same office, each pilot's administrative functions vary considerably and communication happens via telephone or the Internet with external corporations. In-flight radio communication during aerobatics is limited to simple and direct commands, as there can be no room for interpretation errors. In turn, during longer flights, pilots have the chance to carry out conversations through this means of communication.

The final unit of content analysis touched on perception regarding interpersonal relationships at work. Demonstration pilots carry out administrative work shifts in the hangar just like in any other sector of the corporation. However, their work routine is very particular. Almost every day, a group of pilots is absent from the offices, taking turns among them to participate in presentations. During such trips, they are constantly together, both in their accommodations and in social engagements, which explains why most pilots mentioned that time spent together influences the relationship among squadron members.

Most pilots attributed this freedom and highquality relationships to the choice of new members, which is made by EDA members themselves as a way to guarantee harmony among them. All admitted pilots know that they have been selected by their peers to become a part of the group. Furthermore, they put much effort to welcoming new members and their families, promoting a great sense of integration among them. 


\section{Conclusion}

The present ergonomic assessment, which valued subjective data such as the pilots' perceptions regarding their work routine, allowed us to identify that the environmental conditions, change in aircraft direction, PPEs and the aircraft seats were sources of discomfort. Complaints concerning physical overload were especially associated with the upper right limb, but also with the lower limbs and spinal cord. The movement of greatest physical overload was rotating the control stick laterally (external shoulder rotation).

The pilots' discourse regarding interpersonal relationships revealed time spent together as the major factor influencing their relationship, in addition to the fact that the EDA members are responsible for selecting new members, thus guaranteeing harmony among them.

Further multivariate studies should be conducted on the theme, encompassing qualitative and quantitative aspects and investigating data regarding work organization, cognitive aspects and physical assessment of pilots. These researches would provide information on possible muscle overload and examine probable causes of discomfort among demonstration pilots. Thus, health professionals could define necessary changes to their work routine and implement specific physical preparatory training aimed at reducing complaints, improving performance, preventing musculoskeletal problems and increasing quality of life in general.

\section{Acknowledgements}

To the Brazilian Coordination for the Improvement of Higher Education Personnel (Capes), for the doctoral research grant.

\section{References}

1. Walsh IAP, Corral S, Franco RN, Canetti EEF, Alem MER, Coury HJCG. Capacidade para o trabalho em indivíduos com lesões músculo-esqueléticas crônicas. Rev Saúde Pública. 2004;38(2):149-56.
2. Martins MIC, Molinaro A. Reestruturação produtiva e seu impacto nas relações de trabalho nos serviços públicos de saúde no Brasil. Ciênc Saúde Coletiva. 2013;18(6):1667-76.

3. Pereira ESSL, Silva ACC. Impactos das mudanças no processo de trabalho dos profissionais de saúde: o que diz a literatura. Rev Enferm Contemp. 2013; 2(1):209-24.

4. Costa, D, Lacaz FAC, Jackson Filho JM, Vilela RAG. Saúde do Trabalhador no SUS: desafios para uma política pública. Rev Bras Saúde Ocup. 2013;38(127):11-30.

5. Rebouças D, Legay LF, Abelha L. Satisfação com o trabalho e impacto causado nos profissionais de serviço de saúde mental. Rev Saúde Pública. 2007;41(2):244-50.

6. Porto MFS, Juncá DCM, Gonçalves RS, Filhote MIF. Lixo, trabalho e saúde: um estudo de caso com catadores em um aterro metropolitano no Rio de Janeiro, Brasil. Cad Saúde Pública. 2004;20(6):1503-14.

7. Soares JFS, Cezar-Vaz MR, Mendonza-Sassi RA, de Almeida TL, Muccillo-Baisch AL, Soares MCF, et al. Percepção dos trabalhadores avulsos sobre os riscos ocupacionais no porto do Rio Grande, Rio Grande do Sul, Brasil. Cad Saúde Pública. 2008;24(6):1251-9.

8. David GC. Ergonomic methods for assessing exposure to risk factors for work-related musculoskeletal disorders. Occup Med. 2005;55(3):190-9.

9. Stanton N, et al. Handbook of human factors and ergonomics methods. Boca Raton: CRC Press; 2005.

10. William DJ. Conceptualization of risk. In: Karwowsky W, editor. International encyclopedia of ergonomics and human factors [CD-ROM]. 2. ed. New York: Taylor \& Francis; 2006.

11. Wilson JR. Fundamentals of ergonomics in theory and practice. Appl Ergon. 2000;31(6):557-67.

12. Minayo MCS. O desafio do conhecimento: pesquisa qualitativa em saúde. 10. ed. São Paulo: Hucitec; 2007.

13. Tielemans E, Heederik D, Burdorf A, Vermeulen R, Veulemans $\mathrm{H}$, Kromhout $\mathrm{H}$, et al. Assessment of occupational exposures in a general population: comparison of different methods. Occup Environ Med. 1999;56(3):145-51.

14. Corlett EN. Sitting as a hazard. Saf Sci. 2008;46(5): 815-21. 
15. Brasil. Ministério da Aeronáutica. Manual da aeronave EMB 312 T-27 MV050001B.DGN: limites antropométricos. Brasília;1984.

16. Goldspink G. Selective gene expression during adaptation of muscle in response to different physiological demands. Comp Biochem Physiol B Biochem Mol Biol. 1998;120(1):5-15.

17. Temporal WF. Medicina aeroespacial. Rio de Janeiro: Luzes; 2005.

18. Torp S, Grogaard JB. The influence of individual and contextual work factors on workers' compliance with health and safety routines. Appl Ergon. 2009; 40(2):185-93.

19. Bardin L. Análise de conteúdo. Lisboa: Edições $70 ; 1977$.

20. Li L, Lamis F, Wilson SE. Whole-body vibration alters proprioception in the trunk. Int J Ind Ergon. 2008;38(9-10):792-800.

21. Jain PK, Chawla A, Tyagi P. Assessment of cabin conditioning system in a fighter aircraft. Ind J Aerospace Med. 2001;45(2):37-46.

22. Siddiqui IA, Siddiquiz RA. The effect of excessive noise exposure on the hearing thresholds of aviation workers in Karachi. Pak J Med Sci. 2008;24(4):525-30.

23. Rickards CA, Newman DG. G-induced visual and cognitive disturbances in a survey of 65 operational fighter pilots. Aviat Space Environ Med. 2005;76(5):496-500.
24. Goossens RHM, Snijders CJ, Fransen T. Biomechanical analysis of the dimensions of pilot seats in civil aircraft. Appl Ergon. 2000; 31(1): 9-14.

25. Lusted M, Healey S, Mandryk JA. Evaluation of the seating of Qantas flight deck crew. Appl Ergon. 1994;25(5):275-82.

26. Netto KJ, Burnett AF, Coleman JL. Neck exercises compared to muscle activation during aerial combat maneuvers. Aviat Space Environ Med. 2007;78(5):478-84.

27. Silva GV. A influência de problemas na coluna vertebral sobre o desempenho operacional e a segurança de voo na Força aérea Brasileira. Rev. UNIFA. 2005;18(21):4-17.

28. Enoka RM. Neural adaptations with chronic physical activity. J Biomech. 1997;30(5):447-55.

29. Brasil. Instrução Normativa INSS/DC n. 98, de 5 de dezembro de 2003. Aprova Norma Técnica sobre Lesões por Esforços Repetitivos-LER ou Distúrbios Osteomusculares Relacionados ao Trabalho-DORT. Brasília; 2003 [cited 2015 Feb 11]. Available from: http://www010.dataprev.gov.br/sislex/paginas/38/ INSS-DC/2003/98.htm

Received: 04/25/2014 Recebido: 25/04/2014

Approved: 09/22/2014 Aprovado: 22/09/2014 